Bidang ilmu: Gizi Mayarakat

\title{
HUBUNGAN POLA MAKAN, AKTIVITAS FISIK, DAN CITRA TUBUH DENGAN STATUS GIZI LEBIH PADA REMAJA PUTRI DI SMA NEGERI 3 TAMBUN SELATAN
}

\author{
Erina Rizky Damayanti1), Dian Luthfiana Sufyan²) \\ Fakultas Ilmu Kesehatan \\ Universitas Pembangunan Nasional Veteran Jakarta \\ erinarizky98@gmail.com¹); dian.sufyan@upnvj.ac.id ${ }^{2)}$
}

\begin{abstract}
ABSTRAK
Masa remaja merupakan masa terjadinya perkembangan dan pertumbuhan dari aspek fisiologis, psikologis, dan sosial pada masa anak-anak menuju dewasa serta masa remaja rentan akan masalah gizi lebih karena adanya ketidakseimbangan antara asupan makan dan pengeluaran energi melalui aktivitas fisik. Ketidakpuasan akan citra tubuh menjadi perhatian khusus pada remaja putri untuk mengontrol berat badan. Penelitian ini bertujuan untuk mengetahui hubungan antara pola makan, aktivitas fisik, dan citra tubuh dengan status gizi lebih pada remaja putri di SMAN 3 Tambun Selatan. Penelitian menggunakan desain cross sectional dengan metode uji chisquare. Penilaian pola makan dilakukan menggunakan SQ-FFQ, aktivitas fisik dilakukan menggunakan PAL dan citra tubuh dilakukan menggunakan BSQ-16 serta pengukuran antropometri meliputi berat badan dan tinggi badan kepada 58 remaja putri. Hasil analisis menunjukkan bahwa pola makan $(p=0,014)$, aktivitas fisik $(p=0,023)$, dan citra tubuh $(p=0,000)$ memiliki hubungan terhadap status gizi lebih remaja putri $(\mathrm{p}<0,05)$. Hal ini menunjukkan bahwa ada hubungan antara pola makan, aktivitas fisik, dan citra tubuh dengan status gizi lebih pada remaja putri SMAN 3 Tambun Selatan.
\end{abstract}

Kata Kunci: Remaja Putri, Pola Makan, Aktivitas Fisik, Citra Tubuh, Status Gizi Lebih.

\section{ABSTRACT}

Adolescence is a period of development and growth of physiological, psychological, and social aspects in childhood to adulthood and adolescence is prone to more nutritional problems due to an imbalance between eating intake and energy expenditure through physical activity. The dissatisfaction of the body's image is a special concern in female adolescents for weight control. This study aimed to determine the correlation between eating patterns, physical activity, and body image with overnutrition status in female adolescents at SMAN 3 South Tambun. This study uses cross sectional design with chi-square test method. The eating patterns is carried out using SQ-FFQ, physical activity is carried out using PAL and the body image is carried out using BSQ-16 and anthropometry measurements include weight and height for 58 female adolescents. The results of the analysis show that the eating patterns $(p=0,014)$, the physical activity $(p=$ $0,023)$, and body image $(p=0,000)$ Have a correlation to the overnutrition status in female adolescents $(p<$ 0.05). This shows that there was correlation between eating patterns, physical activity, and body image with overnutrition status in female adolescents at SMAN 3 South Tambun.

Keywords: Female Adolescents; Eating Patterns; Physical Activities; Body Image; Overnutrition.

Alamat korespondensi: Perum Graha Prima RT 01 RW 011, No 518 Tambun Utara, Bekasi Timur Email: erinarizky98@gmail.com

Nomor Hp: 08568900798 


\section{PENDAHULUAN}

Perkembangan dan pertumbuhan dari aspek fisiologis, psikologis, dan sosial menuju masa dewasa yang dialami pada transisi anak-anak menuju dewasa awal ialah remaja (Normate dkk., 2017). World Health Organization (WHO) tahun 2018, menyatakan bahwa remaja berusia antara 10-19 tahun. Sekitar 64,19 juta jiwa (24,01\%) di Indonesia merupakan kelompok usia remaja (Badan Pusat Statistik, 2019).

Kelompok usia remaja merupakan salah satu periode rentan mengalami gizi lebih (Kurdanti dkk., 2015). Jika gizi lebih terjadi diusia remaja dan dibiarkan akan terus berlanjut hingga usia dewasa dan lansia (Armadani, 2017). Status gizi lebih berdampak pada peningkatan penderita penyakit tidak menular seperti penyakit kardiovaskular, diabetes, gangguan muskuloskeletal, dan kanker (WHO, 2017). Orang tua yang gemuk berisiko 70-80\% memiliki anak yang gemuk (Kurdanti dkk., 2015). Oleh karena itu, pentingnya pemenuhan gizi dan perhatian terhadap kesehatan remaja, khususnya remaja putri karena perannya sebagai seorang ibu yang akan melahirkan generasi berikutnya, sehingga diharapkan dapat melahirkan anak yang berkualitas dari ibu yang sehat (Setyawati \& Setyowati, 2015).

Gizi lebih dapat berupa overweight dan obesitas (Suharsa \& Sahnaz, 2016). WHO, (2017) mendefinisikan gizi lebih dan obesitas merupakan akumulasi lemak berlebih yang dapat menyebabkan ketidakseimbangan kesehatan. Berdasarkan data RISKESDAS tahun 2018 melaporkan bahwa presentase gizi lebih (IMT/U) remaja usia 16-18 tahun secara nasional ialah gizi gemuk $9,5 \%$, dan obesitas $4 \%$, prevalensi ini mengalami peningkatan dari data RISKESDAS tahun 2013 yaitu gizi gemuk 5,7\% dan obesitas 1,6\%. Provinsi Jawa Barat ialah termasuk salah satu provinsi yang memiliki prevalensi status gizi lebih di atas prevalensi nasional pada remaja usia 1618 tahun yaitu overweight 10,9\%, dan obesitas 4,5\% (Kementerian Kesehatan RI, 2018). Umumnya pola makan yang dapat mempengaruhi status gizi pada remaja (Cahyaning dkk., 2019).

Pola makan merupakan bahan pangan maupun hasil olahannya yang tersusun beranekaragam meliputi jenis, jumlah, dan frekuensi makan yang dikonsumsi oleh remaja (Afrilia \& Festilia, 2018). Pola makan yang tidak seimbang seperti mengkonsumsi makanan melebihi angka kecukupan gizi yang dianjurkan, serta konsumsi makanan yang tidak beragam lebih berisiko mengalami gizi lebih (Mokolensang dkk., 2016). Obesitas dapat terjadi ketika seseorang dengan asupan makan berlebihan yaitu tinggi energi, lemak, karbohidrat, namun rendah serat, maka zat gizi makanan diubah menjadi lemak yang tertimbun didalam tubuh. Akibat dari tidak seimbangnya asupan makan dengan keluaran energi (Mawaddah dkk., 2017).

Asupan energi berasal dari makanan. Didalam makanan yang mengandung karbohirat, protein, dan lemak merupakan zat gizi yang diubah menjadi energi. Kelebihan asupan zat gizi makro, seperti karbohidrat akan tersimpan sebagai glikogen dengan jumlah terbatas dan sisanya lemak, protein akan dibentuk sebagai protein tubuh dan sisanya lemak, sedangkan lemak akan disimpan sebagai lemak. Sehingga banyaknya akumulasi lemak didalam tubuh dapat menyebabkan status gizi lebih pada remaja (Evan dkk., 2017). Pada penelitian Putra, (2017) menyatakan bahwa pola makan berhubungan terhadap overweight, ditunjukkan pada pola makan berlebih mendapat risiko lebih tinggi mengalami overweight $(57,4 \%)$ dibandingkan yang tidak overweight $(42,6 \%)$. Pola makan lebih cenderung memiliki peluang 2,6 kali berisiko mengalami kegemukkan dibandingkan pada pola makan cukup maupun kurang, dikarenakan pola makan berlebih akibat dari makanan yang dikonsumsi diubah menjadi lemak tubuh.

Pada dasarnya, tubuh membutuhkan asupan energi untuk kelangsungan hidup dan beraktivitas, agar dapat mempertahankan berat badan normal diperlukan keseimbangan asupan energi dengan pengeluaran energi melalui aktivitas fisik (Afrilia \& Festilia, 2018).

Aktivitas fisik ialah gerakan tubuh yang diakibatkan dari otot rangka yang membutuhkan pengeluaran energi (WHO, 2016). Terdapat peningkatan prevalensi aktivitas fisik rendah pada usia lebih dari 10 tahun secara nasional tahun 2018 (33,5\%) dibandingkan tahun 2013 (26,1\%) (Kementerian Kesehatan RI, 2018). Pada penelitian Ovita dkk., (2019) ditemukan dari 78 siswi memiliki aktivitas fisik ringan 59 siswi $(75,6 \%)$ dibandingkan aktivitas fisik sedang $(14,1 \%)$ dan berat $(10,3 \%)$. Kurangnya aktivitas fisik berpeluang 3 kali lebih besar menyebabkan gizi lebih 
dibandingkan aktivitas fisik berat (Praditasari \& Sumarmik, 2018). Tidak seimbangnya antara asupan energi berlebih dibandingkan pengeluaran energi, akibat dari kurangnya aktivitas fisik. Maka sisa kalori yang tersimpan didalam tubuh akan membentuk lemak (Putra, 2017). Dan lemak tubuh ditimbun pada tempat-tempat tertentu seperti disimpan di jaringan subkutan 50\%, di sekeliling rongga perut $45 \%$, dan di jaringan intramuskular 5\%. Sehingga memiliki potensi lebih besar untuk mengalami obesitas (Puspitasari, 2018).

Masa remaja banyak terjadi perubahan dari aspek fisik maupun psikologis, tetapi perubahan fisiklah yang terlihat secara nyata, dimana remaja mulai menyukai lawan jenisnya, khususnya pada remaja putri yang lebih memperhatikan bentuk tubuhnya agar telihat menarik didepan lawan jenisnya sehingga remaja putri lebih mementingkan citra tubuhnya (Normate dkk., 2017).

Menurut Honigam \& Castle, (2007) mengatakan bahwa citra tubuh merupakan persepsi seseorang terhadap penampilannya, dan memikirkan kritikan orang lain tentang dirinya, padahal pemikiran dan perasaannya belum tentu sesuai dengan kondisi yang sebenarnya (Nurleli, 2019). Menurut hasil penelitian di Negara India menunjukkan sebagian besar remaja usia dibawah 19 tahun yang memiliki citra tubuh negatif pada remaja putra sebesar $12,5 \%$ dan remaja putri sebesar 40,8\% (Waghachavare dkk., 2014).

Seseorang dengan citra tubuh negatif merasa tidak puas, dan tidak percaya diri terhadap penampilannya. Sedangkan seseorang dengan citra tubuh positif lebih merasa puas, dan percaya diri maka cenderung tidak membatasi pola makannya, sehingga dalam pemilihan makan tidak mementingkan zat gizi pada makanan tersebut, dan pemilihan makan cenderung sembarangan karena hanya berdasarkan kesukaan saja yang mengarah pada makanan cepat saji serta tidak adanya pembatasan dari kuantitas makanan tersebut (Intantiyana dkk., 2018). Namun dilihat dari komposisinya lebih banyak mengandung kalori, lemak, karbohidrat, kolesterol, serta natrium, tetapi rendah serat yang tidak baik bagi tubuh, jika dikonsumsi secara berlebihan dapat menyebabkan obesitas (Serly dkk., 2015). Individu yang hidup pada lingkungan yang menganggap tubuh gemuk adalah tubuh yang sehat maka individu tersebut tidak memikirkan citra tubuhnya dan cenderung menjadikan tubuhnya gemuk (Salam, 2010). Dengan demikian permasalahan persepsi terhadap citra tubuh perlu mendapat perhatian agar tidak terjadi kesalahan pola makan dan permasalahan gizi pada remaja.

Berdasarkan data sekunder dari puskemas setempat yaitu puskemas MangunJaya dari 191 siswi kelas 10 SMA Negeri 3 Tambun Selatan, terdapat 51 siswi (26,7\%) memiliki status gizi lebih yang terdiri dari 34 siswi (17,8\%) gemuk dan 17 siswi (8,9\%) obesitas. Sedangkan status gizi kurus hanya terdapat 2 siswi (1,04\%). Dengan demikian penulis tertarik untuk melakukan penelitian tentang hubungan pola makan, aktivitas fisik, dan citra tubuh dengan status gizi lebih pada remaja putri di SMA Negeri 3 Tambun Selatan. Penelitian ini bertujuan untuk 1) mengetahui karakteristik responden; 2) mengetahui proporsi status gizi lebih, pola makan, aktivitas fisik, dan citra tubuh responden; 3) menganalisis hubungan pola makan dengan status gizi lebih; 4) menganalisis hubungan aktivitas fisik dengan status gizi lebih; 5) menganalisis hubungan citra tubuh dengan status gizi lebih.

\section{METODE PENELITIAN}

Penelitian dilaksanakan pada bulan April 2020 dan bertempat di SMA Negeri 3 Tambun Selatan. Penelitian ini merupakan jenis penelitian observasional analitik dengan desain cross sectional. Populasi dalam penelitian ini adalah siswi kelas X dan XI SMA Negeri 3 Tambun Selatan. Kriteria inklusi dalam penelitian ini adalah 1) Responden siswi berusia 15-18 tahun; 2) Responden yang hadir saat pengambilan data, dan bersedia mengikuti penelitian dengan menandatangani Informed Consent. Berdasarkan perhitungan dengan rumus lemeshow didapatkan jumlah sampel sebesar 58 responden. Prosedur pengambilan sampel dilakukan dengan teknik simple random sampling. Instrumen yang digunakan adalah Formulir penelitian yang berisi informed consent dan identitas responden, Kuesioner Semiquantitative Food Frequency Questionnaire (SQ-FFQ) dengan melakukan wawancara by phone untuk mengetahui pola makan responden, buku foto makanan untuk media penjelasan mengenai estimasi jenis dan ukuran bahan makanan, Kuesioner Physical 
Activity Level (PAL) untuk mengetahui aktivitas fisik responden, dan Kuesioner Body Shape Questionnaire (BSQ-16) untuk mengetahui citra tubuh responden dan telah dilakukan uji validitas dan reliabilitas. Kuesioner dilakukan melalui Google form. Analisis data yang dilakukan yaitu analisis univariat dan analisis bivariat dengan uji chi-square tingkat kemaknaan $95 \%(\alpha=0,05)$. Analisis data dilakukan dengan bantuan software komputer. Penelitian ini telah memperoleh persetujuan dari Komite Etik Penelitian Kesehatan UPNVJ dengan Nomor : 2608/VI/2020/KEPK.

\section{HASIL DAN PEMBAHASAN}

\section{Analisis Univariat}

\section{Gambaran Karakteristik Responden}

Tabel 1. Menunjukkan data usia remaja putri di SMA Negeri 3 Tambun Selatan dapat diketahui bahwa frekuensi terbesar diperoleh pada kategori usia 15-16 tahun sebanyak 50 responden $(86,2 \%)$. Pada usia tersebut tergolong pada tahap remaja tengah (middle adolescence). Remaja memiliki kebutuhan gizi yang besar seiring dengan percepatan pertumbuhan dan perkembangan remaja serta cenderung lebih beraktivitas daripada kelompok usia lainnya, maka pentingnya asupan gizi yang adekuat baik dari kualitas maupun kuantitas makanan (Adriani \& Wirjatmadi, 2016). Pada usia remaja cenderung memilih makanan yang mereka sukai saja dengan jenis yang tidak beragam padahal semakin beragam atau bervariasi makanan maka kebutuhan gizinya semakin terpenuhi yang berdampak terhadap kesehatan dan status gizinya (Sari, 2012).

Tabel 1. Karakteristik Responden

\begin{tabular}{lcc}
\hline \multicolumn{1}{c}{ Variabel } & Frekuensi (N) & Presentasi (\%) \\
\hline Usia Responden (Tahun) & & \\
$15-16$ & 50 & 86,2 \\
$17-18$ & 8 & 13,8 \\
\hline
\end{tabular}

\section{Gambaran Status Gizi pada Remaja Putri di SMA Negeri 3 Tambun Selatan}

Hasil penelitian pada tabel 2. Mengenai distribusi data status gizi remaja putri di SMA Negeri 3 Tambun Selatan menunjukkan bahwa frekuensi terbesar diperoleh pada remaja putri dengan status gizi tidak lebih yaitu 45 responden $(77,6 \%)$. Hal ini sejalan dengan penelitian Yusintha \& Adriyanto, (2018) pada remaja putri di SMAN 1 Sidoarjo menunjukkan hasil yang serupa terdapat 70 responden $(75,2 \%)$ memiliki status gizi tidak lebih sedangkan 23 responden $(24,8 \%)$ memiliki status gizi lebih. Dapat diketahui bahwa status gizi tidak lebih disebabkan oleh perilaku makan yang tidak baik seperti membatasi asupan makannya karena memiliki keinginan untuk diet serta kesibukkan responden yang menjadi alasan untuk meninggalkan waktu makannya khususnya sarapan hal ini dapat membahayakan status gizi dan kesehatan remaja.

Tabel 2. Distribusi Status Gizi Lebih pada Remaja Putri

\begin{tabular}{lcc}
\hline \multicolumn{1}{c}{ Variabel } & Frekuensi (N) & Presentasi (\%) \\
\hline Status Gizi Lebih & & \\
Status Gizi Lebih & 13 & 22,4 \\
Status Gizi Tidak Lebih & 45 & 77,6 \\
\hline
\end{tabular}

\section{Gambaran Pola Makan pada Remaja Putri di SMA Negeri 3 Tambun Selatan}

Berdasarkan data pada tabel 3. Mengenai pola makan remaja putri diketahui sebagian besar remaja putri memiliki pola makan tergolong tidak baik yaitu sebanyak 43 responden $(74,1 \%)$. Hal ini sejalan dengan penelitian Gulo, (2019) pada remaja di SMP Advent Lubuk Pakam yaitu sebagian besar remaja putri memiliki pola makan tidak baik sebesar 25 responden (55,5\%) dibandingkan remaja putri dengan pola makan baik yaitu 20 responden $(44,4 \%)$. Dapat diketahui bahwa pola makan tidak baik disebabkan oleh jenis makan responden masih ada yang jarang mengkonsumsi 
makanan utama, dan jumlah makan responden masih ada yang tergolong kurang, serta frekuensi makan responden masih ada yang melewatkan waktu makannya, sehingga pola makan remaja tergolong tidak baik yang jika berlangsung dalam kurun waktu panjang akan berdampak pada status gizinya.

Tabel 3. Gambaran Pola Makan pada Remaja Putri

\begin{tabular}{lcc}
\hline \multicolumn{1}{c}{ Variabel } & Frekuensi (N) & Presentasi (\%) \\
\hline Pola Makan & & \\
Pola Makan Tidak Baik & 43 & 74,1 \\
Pola Makan Baik & 15 & 25,9 \\
\hline
\end{tabular}

Pola makan dapat dinilai baik atau tidaknya dengan mengukur ketiga komponen pola makan meliputi jenis, jumlah, dan frekuensi makan remaja putri. Pada tabel 4. Dilihat dari jenis makanan sebagian besar remaja putri memiliki jenis makan tergolong baik (93\%), disebabkan karena remaja putri mengonsumsi makanan yang beranekaragam baik itu sumber karbohidrat, protein hewani, nabati, sayur, serta buah. Namun ditemukan beberapa remaja putri dengan jenis makanan tidak baik, disebabkan karena responden belum mengkonsumsi makanan yang beragam, kebanyakan responden tidak mengkonsumsi sayur dan buah, cenderung mengkonsumsi makanan yang disukainya saja dengan jenis yang tidak beragam.. Dilihat dari jumlah makanan sebagian besar remaja putri memiliki jumlah makanan yang tergolong tidak baik (64\%) disebabkan karena memiliki asupan makan $<80 \%$ atau $>110 \%$ AKG. Didapatkan hasil bahwa remaja putri yang asupan makan tergolong $<80 \%$ AKG hal ini dikarenakan remaja putri membatasi pola makannya karena beranggapan takut berat badannya bertambah sehingga berusaha mengurangi porsi makan mereka. Adapun remaja putri yang memiliki asupan makan $>110 \%$ AKG hal ini disebabkan responden memiliki nafsu makan yang besar sehingga cenderung mengonsumsi makanan pokok, lauk pauk, makanan selingan, dan makanan cepat saji dengan jumlah yang cukup banyak dan melebihi kalori yang dibutuhkan. Serta dilihat dari frekuensi makanan remaja putri mayoritas memiliki frekuensi makan tergolong tidak baik, dikarenakan remaja putri memiliki frekuensi makan yaitu lebih dari 3 kali perhari atau kurang dari 3 kali perhari, hal ini akan mempengaruhi pola makan responden menjadi kurang ataupun berlebih. Pola makan baik apabila ketika frekuensi makan perhari sebanyak tiga kali sehari untuk makan utama yaitu makan pagi, siang, dan sore atau malam (Anggraeni, 2015).

Tabel 4. Komponen Pola Makan Remaja Putri

\begin{tabular}{ccc}
\hline Komponen Pola Makan & Frekuensi (N) & Presentasi (\%) \\
\hline Jenis Makanan & 4 & 7 \\
Tidak Baik & 54 & 93 \\
Baik & & \\
Jumlah Makanan & 37 & 64 \\
Tidak Baik & 21 & 36 \\
Baik & 43 & 74 \\
Frekuensi Makanan & 15 & 26 \\
Tidak Baik & & \\
Baik & &
\end{tabular}

\section{Gambaran Aktivitas Fisik pada Remaja Putri di SMA Negeri 3 Tambun Selatan}

Distribusi data pada tabel 5. Mengenai gambaran aktivitas fisik menunjukkan bahwa sebagian besar remaja putri memiliki aktivitas fisik ringan yaitu 38 responden (65,5\%). Aktivitas fisik ringan disebabkan karena sedang dalam masa pandemi Covid-19 yang mengharuskan untuk dirumah saja sehingga responden kurang melakukan aktivitas fisik, responden cenderung melakukan kegiatan duduk, nonton TV/film/youtube, bermain game/gadget, berbaring, dan belajar, 
namun jarang berolahraga sehingga kurang memperhatikan kebugaran tubuhnya, serta sebagian besar responden pergi kesekolah menggunakan angkutan umum dan kendaraan pribadi seperti sepeda motor. Hal ini sejalan dengan penelitian Kusuma, (2018) pada remaja putri di SMAN 7 Surakarta yang menunjukkan bahwa sebagian besar responden memiliki aktivitas fisik ringan sebesar 34 responden (80\%) dibandingkan aktivitas fisik sedang sebesar 9 responden $(20 \%)$.

Tabel 5. Gambaran Aktivitas Fisik pada Remaja Putri

\begin{tabular}{lccc}
\hline & Variabel & Frekuensi (N) & Presentasi (\%) \\
\hline Aktivitas Fisik & & \\
Aktivitas Fisik Ringan & 38 & 65,5 \\
Aktivitas Fisik Sedang & 20 & 34,5 \\
\hline
\end{tabular}

\section{Gambaran Citra Tubuh pada Remaja Putri di SMA Negeri 3 Tambun Selatan}

Distribusi data pada tabel 6. Mengenai gambaran citra tubuh remaja putri menunjukkan bahwa sebagian besar remaja putri memiliki citra tubuh positif sebanyak 40 responden $(69,0 \%)$. Pada penelitian ini responden dengan citra tubuh positif, dikarenakan sebagian besar responden memiliki status gizi tidak lebih oleh karena itu mereka menerima dan puas dengan penampilan dan bentuk tubuhnya. Hasil penelitian ini sejalan dengan penelitian Bimantara dkk., (2019) pada siswi SMAN 9 Surabaya menunjukkan bahwa sebagian besar siswi memiliki citra tubuh positif sebanyak 56 responden $(74 \%)$ dibandingkan siswi dengan citra tubuh negatif 20 responden $(26 \%)$.

Tabel 6. Gambaran Citra Tubuh pada Remaja Putri

\begin{tabular}{lccc}
\hline & Variabel & Frekuensi (N) & Presentasi (\%) \\
\hline Citra Tubuh & & 18 & \\
Citra Tubuh Negatif & 40 & 31,0 \\
Citra Tubuh Positif & & 69,0 \\
\hline
\end{tabular}

\section{Analisis Bivariat}

\section{Hubungan Pola Makan dengan Status Gizi Lebih pada Remaja Putri}

Berdasarkan tabel 7. Hasil analisis hubungan antara pola makan dengan status gizi lebih pada remaja putri diperoleh $p$-value $=0,014(\mathrm{p}<0,05)$ sehingga dapat dinyatakan bahwa ada hubungan yang bermakna antara pola makan dengan status gizi lebih pada remaja putri di SMA Negeri 3 Tambun Selatan.

Pola makan merupakan salah satu faktor yang berperan terhadap kejadian gizi lebih (Wulandari dkk., 2016). Adanya gaya hidup yang beralih kearah westernisasi sehingga merujuk ke pola makan tidak baik dengan makan-makanan cepat saji yang dilihat dari komposisinya lebih banyak mengandung kalori, lemak, karbohidrat, namun rendah serat yang kurang baik bagi tubuh (Mokolensang dkk., 2016). Energi yang berlebihan menyebabkan keseimbangan energi positif yaitu simpanan lemak sebagai cadangan energi. Remaja putri dengan pola makan tidak baik yaitu asupan energi dan lemak akan disimpan berlebihan dalam tubuh, maka jaringan adiposa akan menyekresikan leptin lebih banyak ke dalam peredaran darah. Adanya sel lemak yang berlebihan ini menyebabkan leptin tidak mampu menjalankan fungsinya dengan normal pada penurunan berat badan yang akan mengakibatkan terjadinya resistensi leptin apabila berlangsung terusmenurus. Resistensi leptin dirasakan sebagai tanda lapar dimana setiap makanan yang masuk akan dianggap sebagai rasa lapar oleh otak dan memberikan sinyal secara terus menurus untuk meningkatkan nafsu makan. Kondisi tersebut mengakibatkan kegemukkan yang sulit dikontrol sehingga gizi lebih pada remaja menjadi sulit untuk dihindari (Hardiansyah \& Supariasa, 2017).

Pada penelitian ini ditemukan pola makan tidak baik pada remaja putri dengan status gizi lebih, dikarenakan responden sehari-harinya memiliki asupan makan yang melebihi kebutuhan gizi serta adanya akumulasi pola makan tidak baik dari masa lampaunya, terutama zat gizi makro yang berasal dari makanan cepat saji, snack, dan makanan utama yang diolah dengan cara digoreng. 
Peningkatan berat badan disebabkan karena zat gizi makanan tersebut diubah menjadi lemak tubuh, jika dalam jangka panjang tidak diimbangi dengan pengeluaran energi, maka berdampak pada status gizi lebih. Berdasarkan penelitian Meher \& Nimonkar, (2018) adanya hubungan kebiasaan makan yang salah terhadap kejadian gizi lebih yang pada akhirnya berdampak terhadap penyakit degeneratif seperti diabetes melitus, hipertensi, gangguan kardiovaskular, gangguan hormonal, dan lain-lain.

Penelitian ini sejalan dengan penelitian Cahyaning dkk., (2019) pada remaja di SMPN Kota Malang menyatakan bahwa ada hubungan yang signifikan pola makan terhadap status gizi diperoleh $p$-value $=0,000$. Ditunjukkan bahwa kebiasaan remaja mengkonsumsi fastfood, makanan dan minuman manis dengan kandungan tinggi energi namun nilai gizinya rendah merupakan penyebab terjadinya kegemukkan yang lama kelamaan jika tidak diimbangi dengan aktivitas fisik akan berdampak pada status gizinya menjadi berlebih..

Tabel 7. Tabulasi Siang Antara Pola Makan dengan Status Gizi Lebih pada Remaja Putri

\begin{tabular}{|c|c|c|c|c|c|c|c|}
\hline \multirow{3}{*}{ Pola Makan } & \multicolumn{4}{|c|}{ Status Gizi } & \multirow{2}{*}{\multicolumn{2}{|c|}{ Total }} & \multirow{3}{*}{$p$-value } \\
\hline & \multicolumn{2}{|c|}{ Lebih } & \multicolumn{2}{|c|}{ Tidak Lebih } & & & \\
\hline & $\mathbf{n}$ & $\%$ & $\mathbf{n}$ & $\%$ & $\mathbf{N}$ & $\%$ & \\
\hline Tidak Baik & 13 & 30,2 & 30 & 69,8 & 43 & 100 & \multirow{2}{*}{0,014} \\
\hline Baik & 0 & 0 & 15 & 100 & 15 & 100 & \\
\hline
\end{tabular}

\section{Hubungan Aktivitas Fisik dengan Status Gizi Lebih pada Remaja Putri}

Berdasarkan tabel 8. Hasil analisis hubungan antara aktivitas fisik dengan status gizi lebih pada remaja putri diperoleh $p$-value $=0,023(\mathrm{p}<0,05)$ sehingga dapat dinyatakan bahwa ada hubungan yang bermakna antara aktivitas fisik dengan status gizi lebih pada remaja putri di SMA Negeri 3 Tambun Selatan.

Gizi lebih pada anak dan remaja dapat dipengaruhi oleh aktivitas fisik (Colley dkk., 2013). Disebabkan karena tidak seimbangnya antara banyaknya asupan energi dibandingkan pengeluaran energi merupakan akibat dari aktivitas fisik yang rendah. Oleh karena itu sisa energi yang tersimpan didalam tubuh akan membentuk lemak dan disimpan pada tempat-tempat tertentu sehingga memiliki potensi terhadap kejadian gizi lebih (Putra, 2017). Pada penelitian ini ditemukan bahwa responden dengan aktivitas fisik ringan memiliki presentase lebih besar mengalami status gizi lebih dan tidak lebih dibandingkan dengan aktivitas fisik sedang. Sehingga dapat dikatakan semakin ringan aktivitas fisik akan semakin besar mengalami gizi lebih dan tidak lebih. Pada remaja putri dengan aktivitas fisik ringan memiliki status gizi lebih, dikarenakan sedang dalam masa pandemi Covid-19 yang mengharuskan untuk dirumah saja sehingga responden lebih banyak menghabiskan waktunya dengan melakukan kegiatan duduk, berbaring, nonton tv/film/youtube, bermain game/gadget, belajar, dan melakukan pekerjaan rumah tangga yang ringan, namun jarang melakukan aktivitas fisik. Hal tersebut jika dilakukan dalam jangka waktu panjang dan didukung oleh pola makan tidak baik maka dapat menyebabkan status gizi lebih.

Penelitian ini sejalan dengan penelitian Restuasti dkk., (2016) pada remaja di SMAN 5 Pekanbaru yang menyatakan bahwa ada hubungan yang signifikan aktivitas fisik terhadap kejadian gizi lebih diperoleh $p$-value $=0,012$. Dikarenakan adanya teknologi yang semakin canggih menyebabkan aktivitas fisik remaja menjadi berkurang. Kurang aktivitas fisik akan berdampak terhadap kejadian gizi lebih karena adanya ketidakseimbangan asupan energi yang lebih besar daripada pengeluaran energi.

Tabel 8. Tabulasi Siang Antara Aktivitas Fisik dengan Status Gizi Lebih pada Remaja Putri

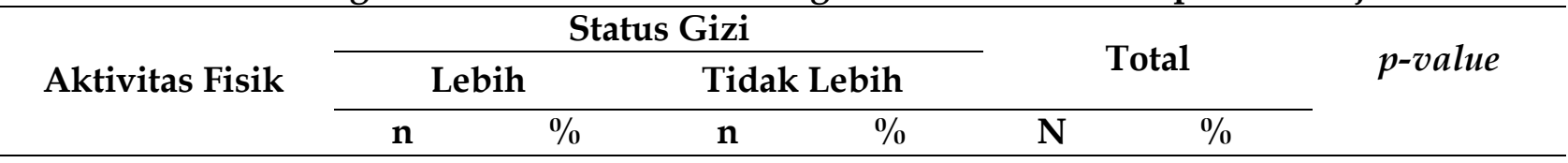




\begin{tabular}{lccccccc}
\hline Ringan & 12 & 31,6 & 26 & 68,4 & 38 & 100 & 0,023 \\
Sedang & 1 & 5,0 & 19 & 95,0 & 20 & 100 & \\
\hline
\end{tabular}

\section{Hubungan Citra Tubuh dengan Status Gizi Lebih pada Remaja Putri}

Berdasarkan tabel 3 hasil analisis hubungan antara citra tubuh dengan status gizi lebih pada remaja putri diperoleh $p$-value $=0,000(\mathrm{p}<0,05)$ sehingga dapat dinyatakan bahwa ada hubungan yang bermakna antara citra tubuh dengan status gizi lebih pada remaja putri di SMA Negeri 3 Tambun Selatan.

Pada penelitian ini ditemukan bahwa remaja putri yang memiliki status gizi lebih merasa bahwa bentuk tubuhnya lebih besar, dibandingkan responden dengan status gizi tidak lebih. Sehingga dapat diketahui bahwa semakin negatif citra tubuh pada remaja putri, maka semakin tidak normal status gizinya (overweight atau obesitas). Remaja putri yang menilai citra tubuhnya secara negatif, mungkin karena remaja putri tersebut telah mengalami gizi lebih. Dikarenakan pada penelitian ini menggunakan desain cross sectional, sehingga hanya dapat mengetahui gambaran hubungan citra tubuh dengan status gizi lebih, dimana kedua variabel tersebut diukur pada satu waktu yang bersamaan. Citra tubuh negatif pada remaja putri disebabkan karena remaja putri menganggap penampilan tubuhnya berbeda dengan bentuk tubuh yang diinginkannya (Hendarini, 2018).

Pada penelitian ini terdapat remaja putri dengan citra tubuh positif namun status gizinya lebih. Dikarenakan remaja putri cenderung tidak membatasi asupan makannya, maka dalam memilih makanan mereka tidak mementingkan kuantitas dan zat gizi pada makanan mereka serta lebih memilih makanan fast food, dan hanya berdasarkan kesukaan terhadap makanan tertentu saja, yang jika dilihat dari komposisi makanan lebih banyak mengandung kalori, lemak, karbohidrat, kolesterol, serta natrium, namun rendah serat yang tidak baik bagi tubuh, dan jika dikonsumsi dalam jumlah besar dapat menyebabkan berat badan lebih (Serly dkk., 2015). Adapun faktor lingkungan yang beranggapan bahwa tubuh gemuk adalah tubuh sehat sehingga individu tersebut tidak memikirkan citra tubuhnya dan cenderung menjadikan tubuhnya gemuk (Salam, 2010).

Penelitian ini sejalan dengan penelitian Kusumaningrum dkk., (2017) pada remaja putri di SMA, SMK, MA Kabupaten Bantul yang menyatakan bahwa ada hubungan citra tubuh terhadap status gizi lebih diperoleh $p$-value $=0,000$. Pada penelitian tersebut menyatakan bahwa remaja putri dengan body image negatif berisiko 7,347 kali lebih besar mengalami status gizi lebih dibandingkan remaja putri dengan body image positif. Disimpulkan bahwa semakin tidak puas body image maka semakin tidak normal status gizinya (overweigth/obesitas), responden merasa bentuk tubuhnya tidak sesuai dengan bentuk tubuh yang diinginkannya akibat dari status gizinya yang berlebih.

Tabel 9. Tabulasi Siang Antara Citra Tubuh dengan Status Gizi Lebih pada Remaja Putri

\begin{tabular}{cccccccc}
\hline \multirow{2}{*}{ Citra Tubuh } & \multicolumn{4}{c}{ Lebih } & \multicolumn{2}{c}{ Tidak Lebih } & \multicolumn{2}{c}{ Total } & \multirow{2}{*}{-value } \\
& $\mathbf{n}$ & $\mathbf{\%}$ & $\mathbf{n}$ & $\mathbf{\%}$ & $\mathbf{N}$ & $\mathbf{\%}$ & \\
\hline Negatif & 10 & 55,6 & 8 & 44,4 & 18 & 100 & \multirow{2}{*}{0,000} \\
Positif & 3 & 7,5 & 37 & 92,5 & 40 & 100 & \\
\hline
\end{tabular}

\section{SIMPULAN}

1. Berdasarkan karakteristik usia remaja putri di SMA Negeri 3 Tambun Selatan tergolong usia 15-16 tahun yaitu sebanyak 50 siswi $(86,2 \%)$

2. Status gizi pada remaja putri di SMA Negeri 3 Tambun Selatan tergolong status gizi tidak lebih yaitu sebanyak 45 siswi $(77,6 \%)$, pola makan tergolong tidak baik yaitu 43 siswi $(74,1 \%)$, aktivitas fisik tergolong ringan yaitu 38 siswi $(65,5 \%)$, dan citra tubuh tergolong positif yaitu 40 siswi $(69,0 \%)$ 
3. Ada hubungan yang bermakna antara Pola Makan dengan status gizi lebih pada remaja putri di SMA Negeri 3 Tambun Selatan ( $p$-value $=0,014$ )

4. Ada hubungan yang bermakna antara Aktivitas Fisik dengan status gizi lebih pada remaja putri di SMA Negeri 3 Tambun Selatan ( $p$-value $=0,023$ )

5. Ada hubungan yang bermakna antara Citra Tubuh dengan status gizi lebih pada remaja putri di SMA Negeri 3 Tambun Selatan ( $p$-value $=0,000)$

\section{SARAN}

1. Diharapkan pihak sekolah SMA Negeri 3 Tambun Selatan dapat mengadakan penyuluhan mengenai pola makan dan citra tubuh yang sehat, menerapkan kantin sehat, serta mengadakan event terkait aktivitas fisik secara rutin

2. Bagi remaja putri yang memiliki status gizi lebih diharapkan dapat memperbaiki pola makannya, dan meningkatkan aktivitas fisiknya, serta remaja putri dengan citra tubuh negatif agar dapat mengubah pola pikirnya serta meningkatkan kepercayaan dirinya

3. Diharapkan penelitian selanjutnya dapat meneliti faktor lain yang dapat mempengaruhi status gizi lebih seperti pengetahuan gizi, besar uang saku, dan sebagainya. Serta diharapkan menggunakan desain eksperimental agar hasil yang didapatkan lebih detail.

\section{DAFTAR PUSTAKA}

Adriani, M., \& Wirjatmadi, B. (2016). Peranan Gizi dalam Siklus Kehidupan (1st ed.). Jakarta: Prenadamedia Group.

Afrilia, D. A., \& Festilia, S. (2018). Hubungan Pola Makan dan Aktifitas Fisik Terhadap Status Gizi di Siswa SMP Al-Azhar Pontianak. Pontianak Nutrition Journal, 1(1), 10-13.

Anggraeni, S. D. (2015). Hubungan Antara Body Image dengan Frekuensi Makan, Jenis Makanan dan Status Gizi Remaja Putri di SMA Negeri 7 Surakarta. Universitas Muhammadiyah Surakarta.

Armadani, D. I. (2017). Hubungan Antara Konsumsi Fast Food, Aktivitas Fisik, dan Status Gizi (Secara Genetik) dengan Gizi Lebih (Studi Pada Siswa Kelas VII, VIII, dan IX Di MTS. Budi Dharma, Wonokromo, Surabaya). Jurnal Pendidikan Olahraga Dan Kesehatan, 5(3), 766-773.

Badan Pusat Statistik. (2019). Statistik Pemuda Indonesia 2019 (D. Susilo, I. E. Harahap, \& R. Sinang (eds.)). Badan Pusat Statistik.

Bimantara, M. D., Adriani, M., \& Suminar, D. R. (2019). Hubungan Citra Tubuh dengan Status Gizi pada Siswi di SMA Negeri 9 Surabaya. Amerta Nutrition, 3(2), 85-88. https:// doi.org/10.2473/amnt.v3i2.2019.85-88

Cahyaning, R. C. D., Supriyadi, \& Kurniawan, A. (2019). Hubungan Pola Konsumsi , Aktivitas Fisik dan Jumlah Uang Saku dengan Status Gizi pada Siswa SMP Negeri di Kota Malang Tahun 2019. Sport Science and Health, 1(1), 22-27.

Colley, R. C., Garriguet, D., Adamo, K. B., Carson, V., Janssen, I., Timmons, B. W., \& Tremblay, M. S. (2013). Physical activity and sedentary behavior during the early years in Canada: a crosssectional study. International Journal of Behavioral Nutrition and Physical Activity, 10(1), 1-9.

Evan, Wiyono, J., \& Candrawati, E. (2017). Hubungan Antara Pola Makan Dengan Kejadian Obesitas Pada Mahasiswa Di Universitas Tribhuwana Tunggadewi Malang. Nursing News: Jurnal Ilmiah Mahasiswa Keperawatan, 2(3), 708-717.

Gulo, I. P. K. (2019). Gambaran Pola Makan dan Status Gizi Remaja di SMP Advent Lubuk Pakam. Politeknik Kesehatan Medan.

Hardiansyah, \& Supariasa, I. D. N. (2017). Ilmu Gizi: Teori \& Aplikasi. Jakarta: Penerbit Buku Kedokteran EGC.

Hendarini, A. T. (2018). Pengaruh Body Image dan Kebiasaan Makan dengan Status Gizi di SMAN 1 Kampar Tahun 2017. Jurnal Gizi, 2(2), 138-145.

Honigam, R., \& Castle, D. J. (2007). Citra Tubuh pada Remaja Putri Menikah dan Memiliki Anak. Jurnal Psikologi, 1(1), 52-62.

Intantiyana, M., Widajanti, L., \& Rahfiludin, M. Z. (2018). Hubungan Citra Tubuh, Aktivitas Fisik 
Dan Pengetahuan Gizi Seimbang Dengan Kejadian Obesitas Pada Remaja Putri Gizi Lebih Di SMA Negeri 9 Kota Semarang. Jurnal Kesehatan Masyarakat (e-Journal), 6(5), 404-412.

Kementerian Kesehatan RI. (2018). Laporan Hasil Riset Kesehatan Dasar (Riskesdas) Indonesia tahun 2018. In Riset Kesehatan Dasar 2018 (pp. 1-674). Badan Penelitian dan Pengembangan Kesehatan.

Kurdanti, W., Suryani, I., Syamsiatun, N. H., Siwi, L. P., Adityanti, M. M., Mustikaningsih, D., \& Sholihah, K. I. (2015). Faktor-faktor yang Mempengaruhi Kejadian Obesitas pada Remaja. Jurnal Gizi Klinik Indonesia, 11(4), 179-190. https:/ / doi.org/10.22146/ijcn.22900

Kusuma, D. (2018). Hubungan Aktivitas Fisik, Pengetahuan Gizi dan Body Image dengan Status Gizi pada Siswi SMAN 7 Surakarta. Universitas Muhammadiyah Surakarta.

Kusumaningrum, A. D., Astiti, D., \& Sariyati, S. (2017). Hubungan Persepsi Tubuh (Body Image) dengan Status Obesitas pada Remaja Putri di SMA, SMK dan MA Kabupaten Bantul. Universitas Alma Ata Yogyakarta.

Mawaddah, N., Jumirah, \& Nasution, E. (2017). Gambaran Pola Makan dan Kejadian Obesitas Pada Masyarakat Suku Gayo Di Desa Titi Pasri Kecamatan Semadam Kabupaten Aceh Tenggara Tahun 2017. 1-10.

Meher, S., \& Nimonkar, R. (2018). Assessment of dietary pattern of school going adolescents in a metro city : a cross sectional study. International Journal of Community Medicine and Public Health, 5(9), 4043-4048.

Mokolensang, O. G., Manampiring, A. E., \& Fatimawali. (2016). Hubungan Pola Makan Dan Obesitas Pada Remaja Di Kota Bitung. Jurnal E-Biomedik, 4(1), 128-135. https:// doi.org/10.35790/ebm.4.1.2016.10848

Normate, E. S., Nur, M. L., \& Toy, S. M. (2017). Hubungan Teman Sebaya, Citra Tubuh Dan Pola Konsumsi Dengan Status Gizi Remaja Putri. Unnes Journal of Public Health, 6(3), 51-57. https:// doi.org/10.15294/ujph.v6i3.17016

Nurleli. (2019). Hubungan Body Image Dengan Status Gizi Remaja Di Kota Makassar. Info Kesehatan, 9(2), 128-133.

Ovita, A. N., Hatmanti, N. M., \& Amin, N. (2019). Hubungan Body Image dan Aktivitas Fisik Dengan Status Gizi Remaja Putri Kelas VII SMPN 20 Surabaya. Sport and Nutrition Journal, 1(1), 27-32.

Praditasari, J. A., \& Sumarmik, S. (2018). Asupan Lemak, Aktivitas Fisik Dan Kegemukan Pada Remaja Putri Di SMP Bina Insani Surabaya. Media Gizi Indonesia, 13(2), 117-122. https:/ / doi.org/10.20473/mgi.v13i2.117-122

Puspitasari, N. (2018). Faktor Kejadian Obesitas Sentral pada Usia Dewasa. HIGEIA Journal of Public Health Research and Development, 2(2), 249-259. https:/ / doi.org/10.15294/higeia.v2i2.21112

Putra, W. N. (2017). Hubungan Pola Makan, Aktivitas Fisik dan Aktivitas Sedentari dengan Overweight di SMA Negeri 5 Surabaya. Jurnal Berkala Epidemiologi, 5(3), 298-310. https:// doi.org/10.20473/jbe.v5i3.2017

Restuasti, T., Jihadi, M., \& Ernalia, Y. (2016). Hubungan Pola Makan dan Aktivitas Fisik Terhadap Obesitas Pada Remaja di SMAN 5 Pekanbaru. Kesehatan Masyarakat, 3(I), 1-20.

Salam, A. (2010). Faktor Risiko Kejadian Obesitas Pada Remaja. Jurnal MKMI, 6(3), 185-190.

Sari, R. I. (2012). Faktor-Faktor Yang Berhubungan Dengan Status Gizi Remaja Usia 12-15 Tahun Di Indonesia Tahun 2007 (Vol. 2012). Universitas Indonesia.

Serly, V., Sofian, A., \& Ernalia, Y. (2015). Hubungan Body Image , Asupan Energi Dan Aktivitas Fisik Dengan Status Gizi Pada Mahasiswa Fakultas Kedokteran Universitas Riau Angkatan 2014. Jurnal FK, 2(2), 1-14.

Setyawati, V. A. V., \& Setyowati, M. (2015). Karakter Gizi Remaja Putri Urban Dan Rural Di Provinsi Jawa Tengah. Jurnal Kesehatan Masyarakat, 11(1), 43-52. https:// doi.org/10.15294/kemas.v11i1.3463

Suharsa, H., \& Sahnaz. (2016). Status gizi lebih dan faktor-faktor lain yang berhubungan pada siswa sekolah dasar Islam Tirtayasa kelas IV dan V di kota Serang Tahun 2014. Jurnal Lingkar Widyaiswara, 3(1), 53-76. 
Waghachavare, V. B., Quraishi, S. R., Dhumale, G. B., \& Gor, A. D. (2014). A cross-sectional study of correlation of body image anxiety with social phobia and their association with depression in the adolescents from a rural area of Sangli district in India. International Journal of Preventive Medicine, 5(12), 1626-1629.

WHO. (2016). Physical Activity. https://www.who.int/health-topics/physical-activity

WHO. (2017). Obesity and Overweight. https://www.who.int/news-room/factsheets/detail/obesity-and-overweight

WHO. (2018). Kesehatan Remaja Di Wilayah Asia Tenggara. https:// www.who.int/southeastasia/health-topics/adolescent-health

Wulandari, S., Lestari, H., \& Fachlevy, A. F. (2016). Faktor yang Berhubungan dengan Kejadian Obesitas pada Remaja di SMA Negeri 4 Kendari Tahun 2016. 1-13.

Yusintha, A. N., \& Adriyanto. (2018). Hubungan Antara Perilaku Makan dan Citra Tubuh dengan Status Gizi Remaja Putri Usia 15-18 Tahun. Amerta Nutr, 2(2), 147-154. 
